Acta Technologica Agriculturae 3

Nitra, Slovaca Universitas Agriculturae Nitriae, 2021, pp. 136-142

\title{
WATER CONSUMPTION IN THE AUTOMATIC MILKING SYSTEMS
}

\author{
Petr VACULÍK'1, Tomáš JEHLIČKA', Viera KAŽIMÍROVÁ2* , Andrea SMEJTKOVÁ ${ }^{1}$ \\ ${ }^{1}$ Czech University of Life Sciences Prague, Czech Republic \\ ${ }^{2}$ Slovak University of Agriculture in Nitra, Slovak Republic
}

\begin{abstract}
The article deals with the determination of water consumption at selected dairy farms during milking using automatic milking systems (AMS). The aim was to determine the water consumption during basic activities associated with the AMS use, namely water for cleaning the milking set and water for cleaning and disinfecting the entire milking system at set daily intervals (hereinafter water). The research was carried out at seven farms in the Czech Republic, which house dairy cows of the black-spotted Holstein cattle. The evaluated groups of dairy cows had from 97 to 103 milked cows for the entire monitored period. Based on the performed measurements, it was found that the average amount of water consumed by AMS per 1 litre of milked milk was 0.33 litres. The results show that water consumption is not completely constant during the year. Multiple factors, including performance, the number of non-drinking milk detections, animal health and current climatic conditions, influence it.
\end{abstract}

Keywords: cattle; cleaning; dairy farm; Lely; milking robot

Rational water management is a very topical issue, as the relatively sharp increase in human population and rising living standards are among the main causes leading to an increase in water consumption worldwide. According to the World Economic Forum, the so-called water crisis is one of the ten biggest issues that humanity has to face today. Approximately $70 \%$ of the world's water consumption is related to agriculture, and in the future, it can be assumed that this value will increase even more in order to cover higher demands for food (Bosire et al., 2015).

Livestock production, and dairy farming and milking in particular, is an area of agriculture that is very demanding in terms of water consumption. Water use in dairy production is a matter of discussion all over the world, because water scarcity and water pollution are issues of concern in a large number of regions. Concurrently, climate change has also become an emerging concern for most dairy producers (Sultana et al., 2014). Dairy cattle account for approx. $19 \%$ of the world's total water footprint related to animal production (Hoekstra, 2012). The production of milk and dairy products is one of the main production commodities of agriculture. Considering the dairy farming, the energy intensity evaluation of breeding has become frequently discussed topic in the last few decades, especially in regard to the issues of machine milking (Přikryl et al., 2015), relationship between people and machines (Přikryl et al., 2016), automation, and more advanced robotization of individual activities (Brouček and Tongel', 2015; Deming et al., 2013; Hansen et al., 2019). Activities utilizing the highest degree of automation (robotization) include the process of machine milking using AMS (automatic milking system). The AMS use is one of the current trends in breeding of cows with marketable milk production and the number of installed machines is rapidly growing each year. In general, emphasis is placed on the efficiency and energy efficiency of technology used in agriculture (Kirsanov et al., 2020; Mihina et al., 2018), livestock welfare (Lendelová et al., 2017), and impacts of agriculture on the environment (Noya et al., 2018; White, 2016). In cattle farming with marketable milk production, water is consumed to meet the physiological needs of animals and ensure farm operation. Miglierina et al. (2018) and Ridoutt and Pfister (2010) dealt with the issue of water consumption in dairy farms and its impacts on the environment.

This article deals with water consumption at selected dairy farms during the actual milking process using AMS, i.e. milking robots.

\section{Material and methods}

In order to determine the water consumption at selected dairy farms during milking using AMS, seven farms under specific climatic conditions of the Czech Republic were monitored. These farms house the black-spotted Holstein cattle breed. Measurements at all farms took place since 2 January 2019 to 29 December 2019. Evaluated groups of dairy cows at individual farms ranged from 97 to 103 milked animals during the entire monitored period (i.e. the measurements were targeted at herds with approx. 100 milked animals for the purposes of measurement comparability). The number of animals in one herd during the observed period, i.e. one year, cannot be constant due to technical and organizational reasons. Monitored groups of animals were housed in new or reconstructed stables, to which the technology of free housing together with AMS 
(milking robots) were applied. The breeding technology was in full compliance with all animal welfare requirements and other standards related to relevant regulations.

Milking robots were used at the monitored farms for at least 1 to 6 years prior to monitored period, and thus the herd management completely relied on the maximum use of this technology. During the monitored period, the same type of AMS (by the same manufacturer and with comparable technical parameters) was installed at the farms. It was an AMS by Lely. The milking robots utilize water in numerous activities. The AMS central control unit provides the distribution of electricity; water; water heating to the required temperature; air pressure and vacuum distribution; and data communication for robotic milking units.

Water used was either clean or mixed with disinfectants. Disinfection was performed according to the specified program using water at different temperatures and with different content of disinfectants; furthermore, certain parts of the milking system were disinfected even after each milking cycle (teat cups, decoupling valves, cleaning brushes). A more extensive flushing was automatically performed after each detection of non-drinking milk. Based on the system settings, the main overall flushing of all components from the milk pipeline to collection tank was performed using a hot water with disinfectants (usually three times a day). An operator changed the particulate filter in milk pipeline at the of the AMS outlet at regular intervals. The AMS described made it possible to disinfect the teat cups after each milking with steam under pressure (steam is generated by a steam generator).

In this work, the monitored water consumption was related only to milking using AMS. The water consumption related to maintenance of technological equipment (i.e. for cleaning AMS boxes) and housing areas, watering and cleaning of animals, ensuring the optimal thermal conditions in breeding, etc., was not taken into account.

To determine the water consumption during the basic activities associated with the use of AMS, an electronic water metre KADEN S 060 with remote reading was installed at the water connection to each AMS. This water metre is certified according to the European MID regulations (EEC 2004/22/
EC). Data from the water metre were read at regular intervals of several days and subsequently evaluated.

In addition to this, the number of milkings per day, the amount of milk milked per day, and the number of detections of non-drinking milk with subsequent flushing per day were read from the operating software of each AMS at regular intervals of several days.

Furthermore, the amount of water consumed per milking, the water consumption per 1 litre of milked milk, and the amount of water consumed by AMS flushing after detection of non-drinking milk per day were calculated.

This paper does not evaluate individual farms separately, but the final data set is observed as a whole within the monitored period. For the evaluation and interpretation of results, specific values, e.g. the average water consumption per milking, etc., were subsequently calculated.

Statistical analysis was performed using the Excel program. In order to obtain the means and deviations of measured parameters, the ANOVA analysis was conducted on the test variants at significance level of 0.05 .

\section{Results and discussion}

Figures 1-6 show all data set values obtained by measurements at monitored farms as a whole. The results represent the arithmetic mean of values measured at monitored farms.

Figure 1 shows the average number of milkings of a group of dairy cows per day. The average set values range from 259 to 275 of milkings per day in the evaluated groups of dairy cows. The curve of the number of milkings shows that lower values were recorded in January, February, October and November; moreover, a higher number of milkings was observed in July and September. Individual dairy cows were milked 2.7 times a day on average.

Figure 2 shows the average amount of milked milk per day in the evaluated groups of dairy cows during the entire monitored period. The amount of milk milked per day shows that an average of 2560 litres of milk was milked per day (based on the average number of cows in the monitored group), with lower group yield in the winter months and

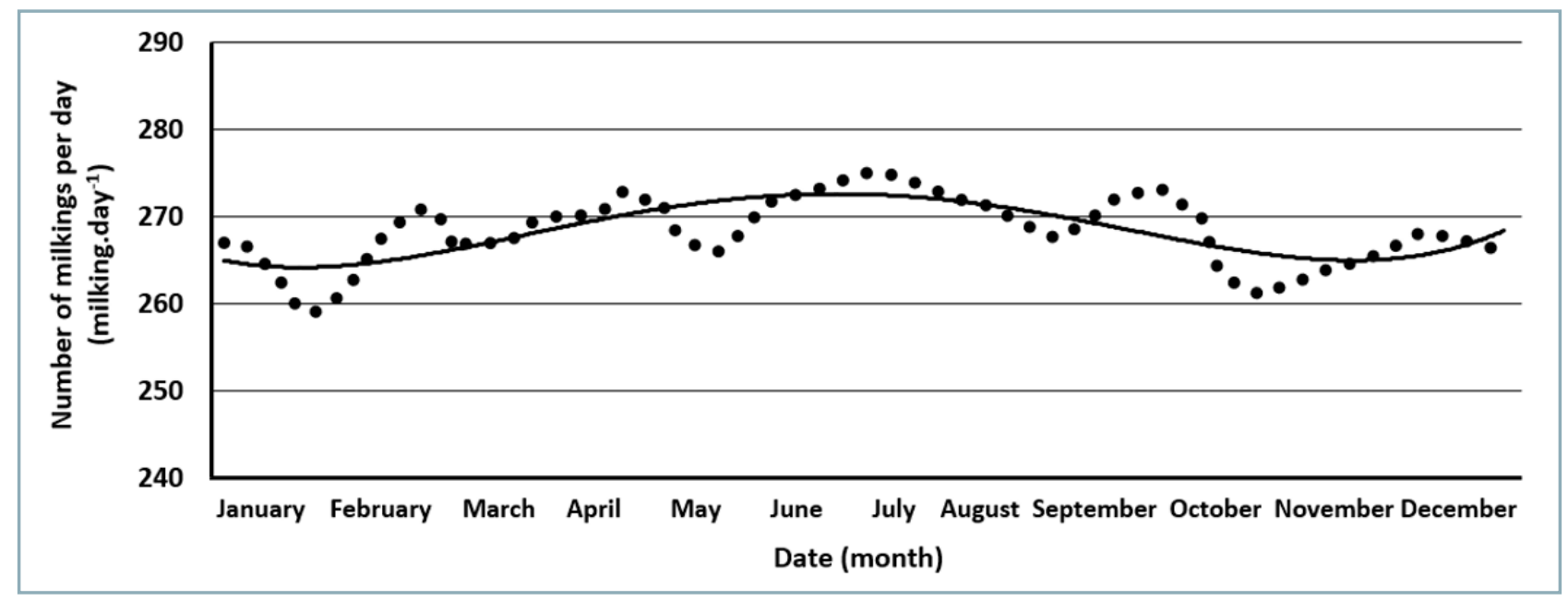

Fig. 1 Average number of milkings per day 


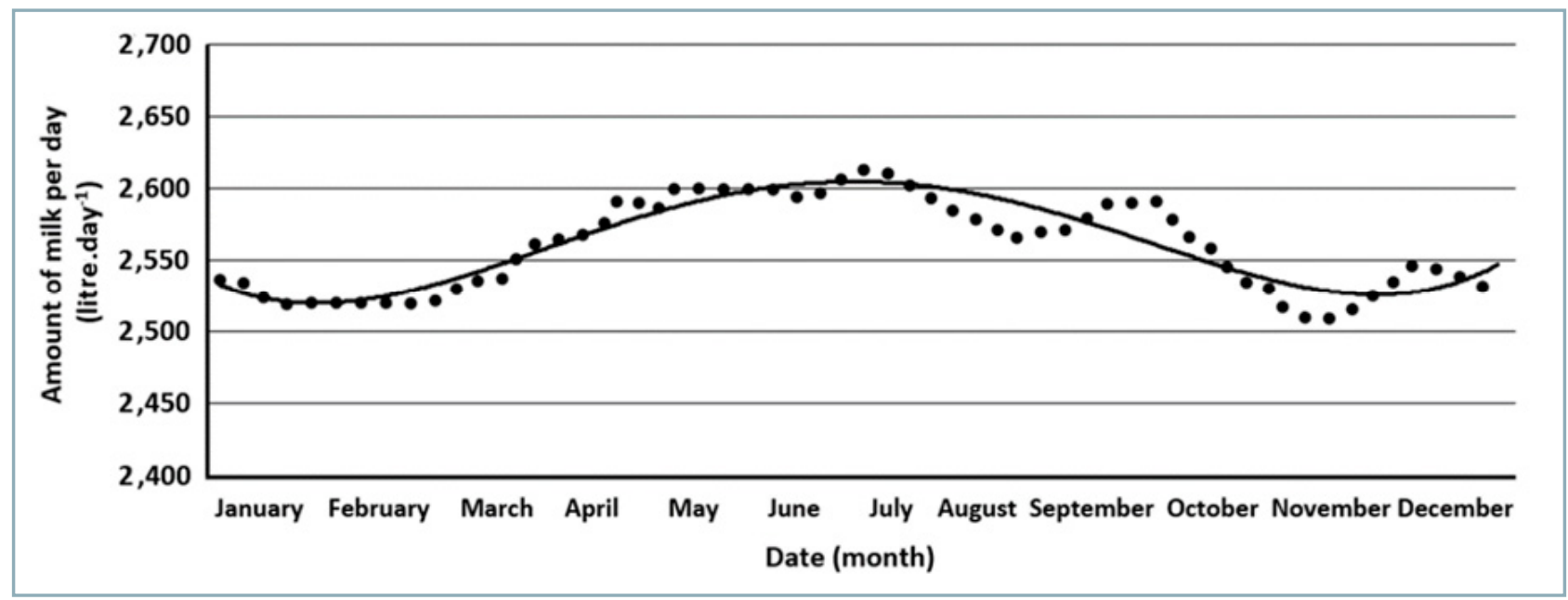

Fig. 2 Average amount of milked milk per day

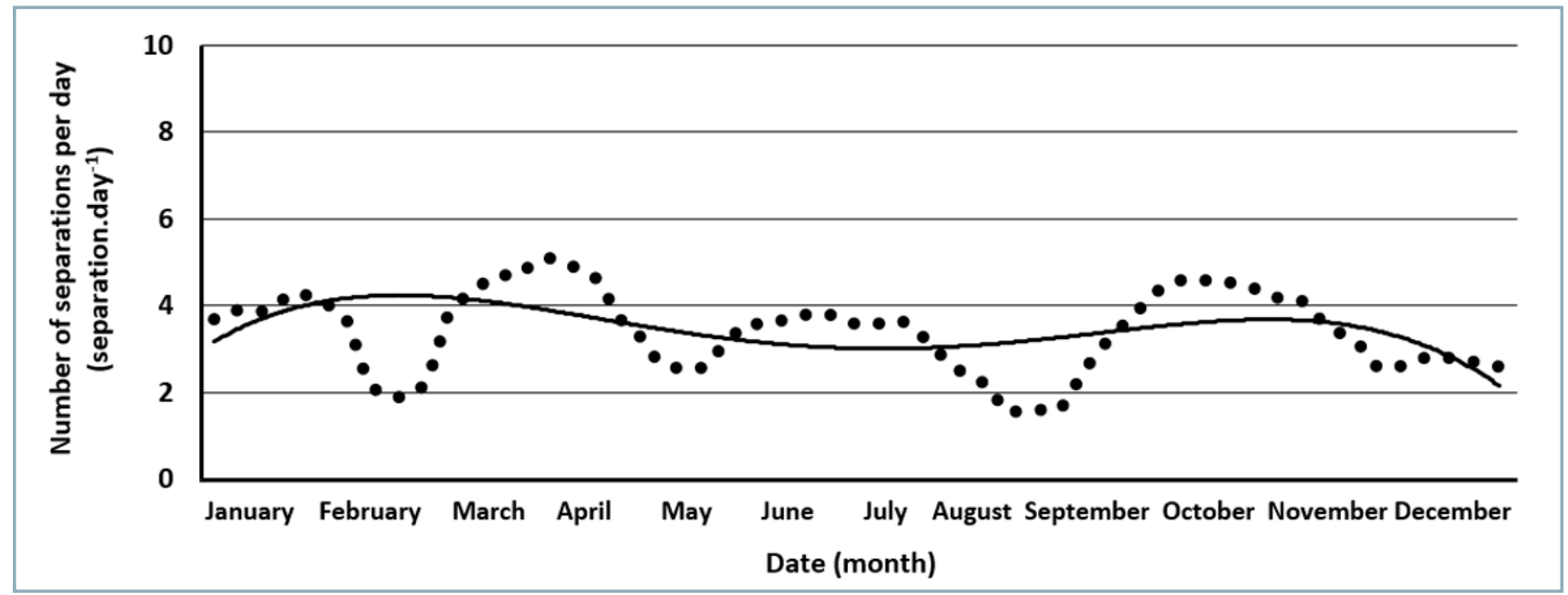

Fig. 3 Average number of detections of non-drinking milk with subsequent flushing per day

higher group yield in months with higher temperatures, i.e. May, June, July and September. The higher group milk yield can be caused by a change in climatic conditions, which would result in better animal welfare. In general, there might be multiple factors affecting the amount of milked milk per day. In the monitored groups, in which the total number of monitored animals was approx. 700, majority of individual factors affecting the milking may be not taken into account. Ultimately, this increase in the group milk yield during summer months can be explained by the higher average environment temperature.

The average determined values range from 2508 to 2613 litres of milked milk per day in the evaluated groups. The amount of milked milk at the monitored farms was relatively even for the entire monitored period, i.e. fluctuation of values from 2508 to 2613 litres of milked milk per day is not considered very significant.

Figure 3 shows the average number of detections of nondrinking milk followed by flushing per day in the evaluated groups of dairy cows for the entire monitored period. The measurement results show that, on average, non-drinking milk was detected 3.5 times a day in each evaluated group. The average determined values range from 1.60 to 5.10 of detections per day in the evaluated groups. It is not possible to clearly state the causes of higher or lower measured number of detections. There may be several factors affecting the number of detections; nevertheless, they occurred randomly and are not the subject of this research. However, the number of detections significantly affects the daily water consumption for milking.

Figure 4 shows the average amount of water consumed in AMS flushing after the detection of non-drinking milk per day in the evaluated groups of dairy cows for the entire monitored period. These values are related to the average number of detections of non-drinking milk. After the detection of non-drinking milk by the AMS quality control system, the milk pipeline is flushed (a uniform amount of 13 litres of water was set for flushing at the evaluated farms). On average, 45.4 litres of water were consumed daily for this activity in each evaluated group of dairy cows. During the monitored period, the water consumption in flushing after detection fluctuated in the interval from 20.8 to 66.3 litres of water per day in the evaluated groups. Relatively significant deviations between individual farms were caused by the placement of machines in housing area, therefore, a reason for this lies in a different construction length of milk pipelines 


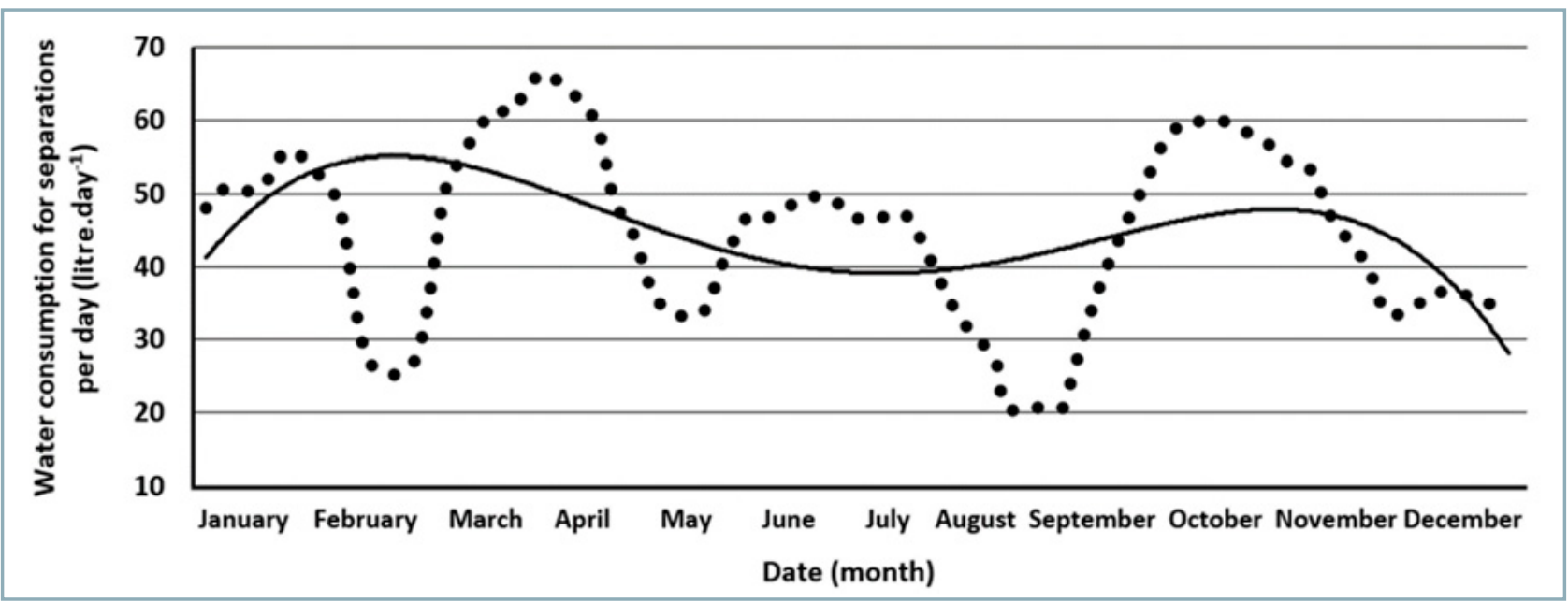

Fig. 4 Average amount of water consumed in flushing the AMS after detection of non-drinking milk per day

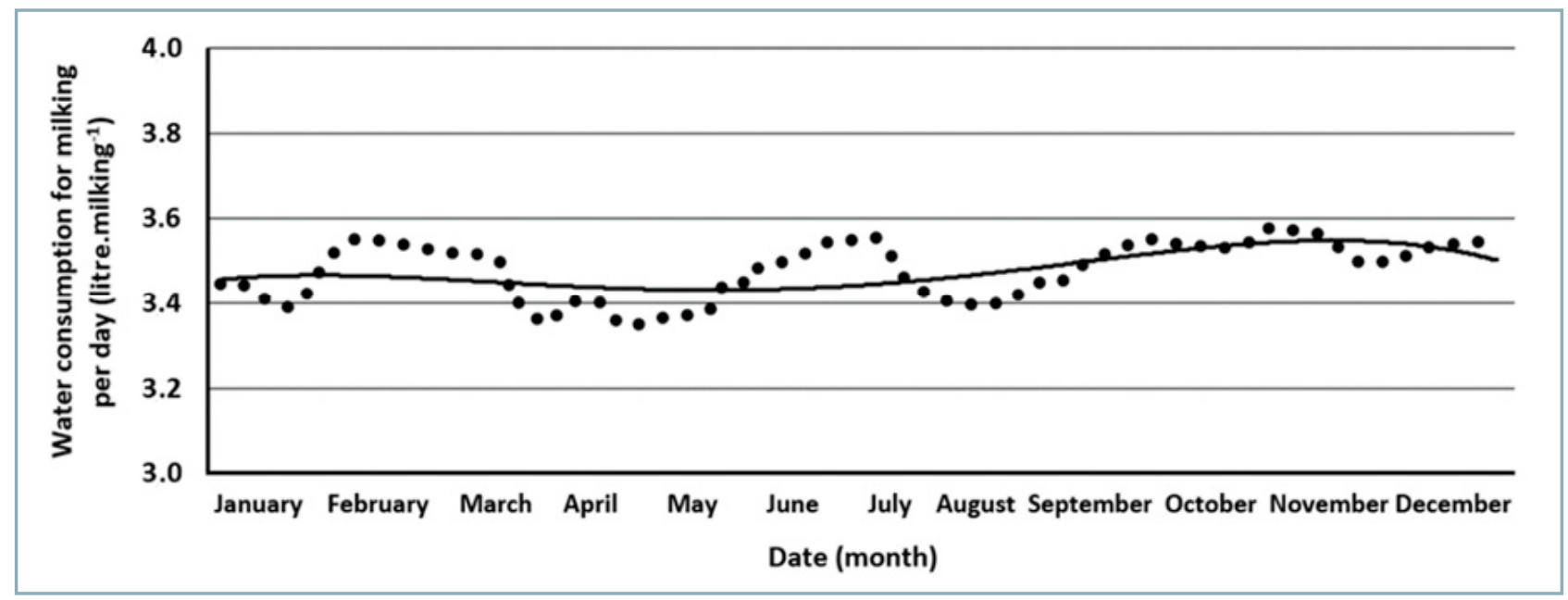

Fig. 5 Average amount of water consumed per one milking

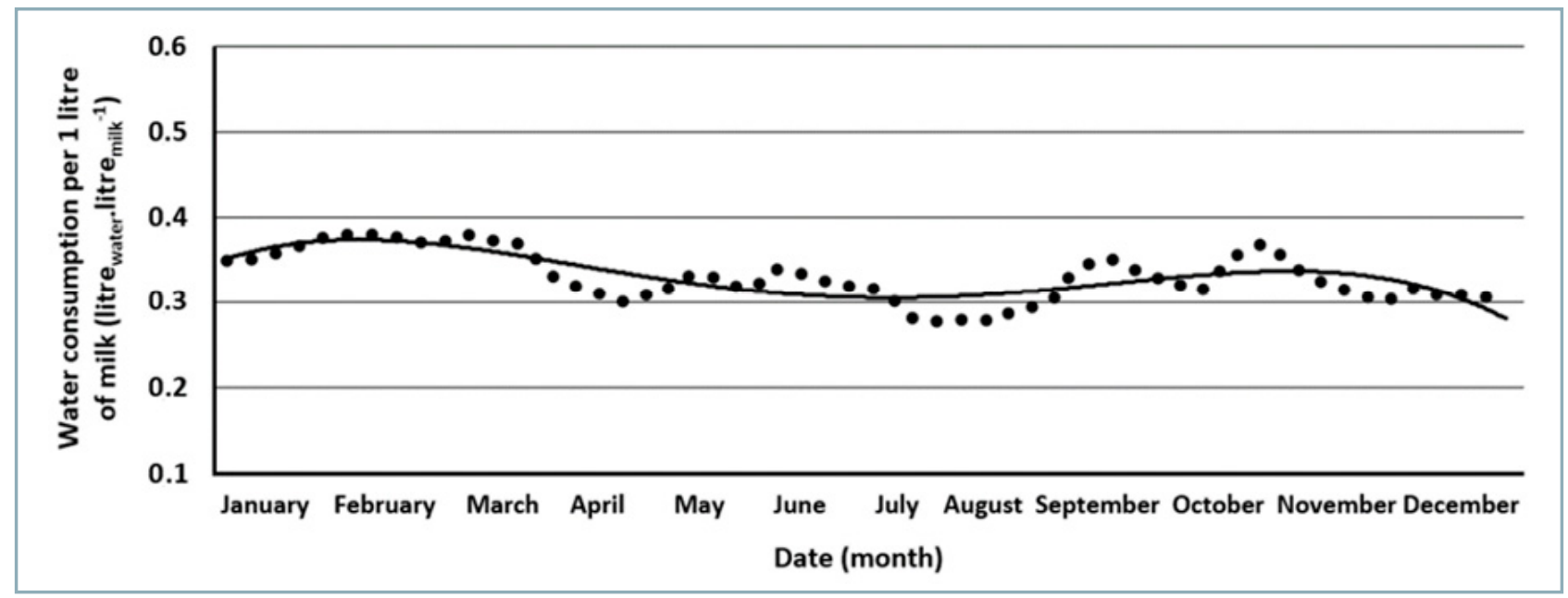

Fig. 6 Average water consumption per 1 litre of milk 
between the AMS and dairy room, satisfying thus different needs of a specific breeder and a given object.

Figure 5 shows the average amount of water consumed by AMS per one milking for the entire monitored period. The amount of water consumed by AMS per one milking shows that 3.48 litres of water were used for this activity on average. This value includes water consumption for detection and regular daily cleaning of the AMS. The lowest amounts of water consumed per milking were reached in January, April, May and August, while the highest amounts were recorded in February, July, October and December. The average set values in the evaluated groups of dairy cows range from 3.35 to 3.55 litres of water per milking, indicating a relatively balanced consumption.

Figure 6 shows the average amount of water consumed by AMS per 1 litre of milked milk throughout the monitored period. The graph shows that 0.33 litres of water were consumed per 1 litre of milk on average. The lowest amounts of water consumed per milking were reached in April, May, July and November, the highest in January, February, September and October. The average set values in the evaluated groups of dairy cows range from 0.28 to 0.38 litres of water per 1 litre of milked milk, suggesting a very balanced course.

Based on the determined average values of all evaluated groups of dairy cows, the dependences of water consumption in AMS flushing after detection of nondrinking milk on the number of milkings, as well as on the amount of milked milk (per 1 litre of milk) were tested by analysis of variance (ANOVA). The analysis of variance results of measured water consumption values are given in Table 1.

The resulting measured water consumption by AMS is given in Table 2.

Analysis of variance at 0.05 level of significance revealed that the water consumption in AMS flushing is significantly dependent on the number of detections of non-drinking

Table 1 Analysis of variance of measured water consumption values (default value of the Alfa significance level is 0.05)

\begin{tabular}{|c||c|c|c|c|c|}
\hline Source of variability & Total variability & $\begin{array}{c}\text { Mean value } \\
\text { of variability }\end{array}$ & Test criterion & $\begin{array}{c}\text { Significance level } \\
\text { Critical test } \\
\text { criterion }\end{array}$ \\
\cline { 2 - 5 } & SS & MS & F & P & $\mathbf{F}_{\text {crit }}$ \\
\hline
\end{tabular}

Analysis of variance of average water consumption in AMS flushing after the detection of non-drinking milk per day

\begin{tabular}{|l||c|c|c|c|}
\hline Intermediate selections & 55068.42 & 1079.77 & 40.53 & 0.87 \\
\hline All selections & 8311.64 & 26.64 & - & - \\
\hline Total & 63380.06 & - & - & - \\
\hline
\end{tabular}

$\mathrm{F}>\mathrm{F}_{\text {crit }}$ (the alternative hypothesis applies) - water consumption in AMS flushing depends on the number of non-drinking milk detections

Analysis of variance of average amount of water consumed by AMS per number of milkings

\begin{tabular}{|l||c|c|c|c|}
\hline Intermediate selections & 12.70 & 0.25 & 2.37 & 1.43 \\
\hline All selections & 320.80 & 1.03 & - & - \\
\hline Total & 333.49 & - & - & - \\
\hline
\end{tabular}

$\mathrm{F}>\mathrm{F}_{\text {crit }}$ (the alternative hypothesis applies) - water consumption in AMS cleaning depends on the number of milkings

\begin{tabular}{|l||c|c|c|c|c|}
\hline \multicolumn{5}{|c|}{ Analysis of variance of the dependence of water consumption per 1 litre of milk } \\
\hline Intermediate selections & 0.28 & 0.01 & 4.28 & -0.72 \\
\hline All selections & 0.41 & 0.01 & - & - \\
\hline Total & 0.69 & - & - & - \\
\hline F & - & - & - \\
\hline
\end{tabular}

$\mathrm{F}>\mathrm{F}_{\text {crit }}$ (the alternative hypothesis applies) - the water consumption in AMS flushing depends on the amount of milked milk

Table 2 AMS cleaning water demands

\begin{tabular}{|c|c|c|c|c|}
\hline Unit & Mean & Standard deviation & Min & Max \\
\hline \multicolumn{5}{|c|}{ Average amount of water consumed in AMS flushing after detection of non-drinking milk per day } \\
\hline$I_{\text {water }} \cdot \mathrm{AMS}^{-1} \cdot$ day $^{-1}$ & 45.40 & 12.17 & 20.80 & 66.30 \\
\hline \multicolumn{5}{|c|}{ Average amount of water consumed by AMS per dairy cow per day } \\
\hline$I_{\text {water }} \cdot \operatorname{cow}^{-1} \cdot$ day $^{-1}$ & 9.40 & 0.19 & 9.05 & 9.59 \\
\hline \multicolumn{5}{|c|}{ Average amount of water consumed per one milking } \\
\hline $\mathrm{I}_{\text {water }} \cdot$ milking $^{-1}$ & 3.48 & 0.07 & 3.35 & 3.55 \\
\hline \multicolumn{5}{|c|}{ Average amount of water consumed per 1 litre of milk } \\
\hline$I_{\text {water }} \cdot I_{\text {milk }}{ }^{-1}$ & 0.33 & 0.03 & 0.28 & 0.38 \\
\hline
\end{tabular}


milk and the amount of milked milk; there is also a clear dependence on the number of milkings.

Similar values of water consumption per 1 litre of milk were also observed by Rasmussen and Pedersen (2004); the authors stated that the amount of water consumed when using AMS ranges from 250 to 350 litres of water per ton of milk, i.e. approx. 0.25 to 0.35 litres of water per litre of milk.

The work presented does not deal with the water consumption during conventional milking in milking parlours. Williams (2009) gives the water consumption for 100 cows in the interval between 6500 and 18000 litres of water per 24 hours, and these values were obtained by monitoring of 1500 conventional milking parlours. The large differences in obtained values confirm the significant influence of operator on water consumption. The milking parlour design impacts on the water consumption can also be significant, e.g. water consumption in herringbone milking parlours averages approx. 876 litres of water per 24 hours (150 litres of water per ton of milk), while it reaches up to 1900 litres of water per 24 hours in rotary milking parlours (500 litres of water per ton of milk) (Rasmussen and Pedersen, 2004). Williams (2009) further states that a linear relationship can be observed between herd size and water consumption in milking parlours. With herd size, water consumption increases linearly, regardless of the design of the milking parlour. Vander-Zaag et al. (2018) demonstrated that the water used per kilogram of milk produced was affected not only by changes in water use but also by changes in herd-scale milk production. Robinson et al. (2016) observed that the free-stall robotic milking systems used more water than the tie-stall and free-stall parlour systems. Furthermore, Thomson and Corscadden (2018) stated that water use per cow per day for just the AMS system demonstrated a range between 8 and 24 litres, whereas it was 8.30 litres per cow per day and 3.75 litres per litre milk for the Lely system. On the contrary, Krauss et al. (2016) found out that, for cleaning the AMS, $2.50 \mathrm{~m}^{3}$ of water was used per day on average. Regarding the milk yield of the cows, 0.80 litres of water was used per kg of milk; for cleaning the herringbone milking parlour, $3.10 \mathrm{~m}^{3}$ of water was used per day, which is more than it is necessary for the AMS.

To get a better picture of the values of water consumption in milking by AMS, it is vital to take into account the overall amount of water necessary for feeding and watering, which is dependent mainly on the cattle breed, lactation phase, and outdoor environment temperature. Whether the cattle are bred in pastures or stables also represents an important aspect in this (Golher et al., 2021). It is still necessary to look for ways to reduce water consumption in cattle breeding, e.g. by building new stables or renovating existing ones in such a manner that there would be no need for water utilization for the purposes of cooling the housing areas in the summer months. Another possibility of saving water would be related to a more extensive utilization of rainwater, either treated or untreated. It can serve a number of purposes, especially cleaning of stable areas, cooling animals, and others. Furthermore, strict following of procedures by the staff (which should be financially motivated towards environmentally friendly conduct) also represents a space for improvement in terms of water consumption in cattle breeding.

\section{Conclusion}

In order to determine the water consumption at selected dairy farms during milking using AMS, the following values of water consumption were determined experimentally.

The average amount of water consumed by AMS per milking was 3.48 litres, while the average values for the entire monitored period ranged from 3.35 to 3.55 litres of water. The average amount of water consumed by AMS per 1 litre of milked milk was 0.33 litres and the average values for the entire monitored period ranged from 0.28 to 0.38 litres.

The average amount of water consumed in flushing the AMS after detection of non-drinking milk per day was 45.4 litres of water per group of dairy cows, i.e. 100 pcs. During the monitored period, the values of water consumption for flushing after detection fluctuated in the interval from 20.80 to 66.30 litres of water per day per group of dairy cows. This value is clearly related to the hygiene of breeding and current state of health of animals, which must be rigorously and intensively evaluated and any changes in animal health must be appropriately and timely addressed.

Analysis of variance at 0.05 significance level revealed that the water consumption in AMS flushing is significantly dependent on the number of detections of non-drinking milk and the amount of milked milk; moreover, there is also a clear dependence on the number of milkings.

Measured values show that the water consumption is not completely constant during the year. It is influenced by several factors, including performance, number of detections of non-drinking milk that are clearly related to animal health, and current climatic conditions. It can be thus stated that the basic precondition for optimal dairy farming - or optimal water consumption during milking using AMS - is the strict following of all welfare breeding principles.

Finally, it can be concluded that milking by means of AMS enables careful water management regardless of discipline of employees, which is often a big issue in terms of conventional methods of milking. Milking using AMS significantly eliminates errors caused by the human factor.

\section{Acknowledgements}

This article was financially supported by the Faculty of Engineering of Czech University of Life Sciences Prague (Internal Grant Agency of Faculty of Engineering (IGA TF) Internal Project No. IGA TF 2019:31170/1312/3121).

\section{References}

BOSIRE, C. K. - OGUTU, J. O. - SAID, M. Y. - KROL, M. S. - DE LEEUW, J. - HOEKSTRA, A. Y. 2015. Trends and spatial variation in water and land footprints of meat and milk production systems in Kenya. In Agriculture, Ecosystems and Environment, vol. 205, pp. 36-47.

BROUČEK, J. - TONGEL, P. 2015. Adaptability of dairy cows to robotic milking. In Slovak Journal of Animal Science, vol. 48, no. 2, pp. 86-95.

DEMING, J. A. - BERGERON, R. - LESLIE, K. E. - DEVRIES, T. J. 2013. Associations of housing, management, milking activity, and standing and lying behaviour of dairy cows milked in automatic systems. In Journal of Dairy Science, vol. 96, no. 1, pp. 344-351. 
GOLHER, D. M. - PATEL, B. H. M - BHOITE, S. H. - SYED, M I. - PANCHBHAI, G. J. - THIRUMURUGAN, P. 2021. Factors influencing water intake in dairy cows: a review. In International Journal of Biometeorology, vol. 65, no. 4, pp. 617-625.

HANSEN, B. G. - HERJE, H. O. - HOVA, J. 2019. Profitability on dairy farms with automatic milking systems compared to farms with conventional milking systems. In International Food and Agribusiness Management Review, vol. 22, no. 2, pp. 215-228.

HOEKSTRA, A. Y. 2012. The hidden water resource use behind meat and dairy. In Animal Frontiers, vol. 2, no. 2, pp. 3-8.

KRAUSS, M. - DRASTIG, K. - PROCHNOW, A. - ROSE-MAYERHOEFER, S. - KRAATZ, S. 2016. Drinking and cleaning water use in dairy cow barn. In Water, vol. 8, no. 7, article no. 302.

KIRSANOV, V. V. - MATVEEV, V. YU. - Maslov, M. M. - ZAIKIN, W. P. ERZAMAEV, M. P. 2020. Influence of devices for cleaning the milk pipes of the milking units on the ecology of milk production. In IOP Conference Series: Earth and Environmental Science, vol. 422 article no. 012075.

LENDELOVÁ, J. - KARANDUŠOVSKÁ, I. - ŽITŇÁK, M. - BOĎO, Š. MIHINA, Š. 2017. Effect of climatic conditions on differences in thermo-technical properties of organic bedding in laboratory testing. In Acta Technologica Agriculturae, vol. 20, no. 1, pp. 1-6.

MIGLIERINA, M. M. - BONADEO, N. - ORNSTEIN, A. M. - BECÚVILLALOBOS, D. - LACAU-MENGIDO, I. M. 2018. In situ provision of drinking water to grazing dairy cows improves milk production. In New Zealand Veterinary Journal, vol. 66, no. 1, pp. 37-40.

MIHINA, Š. - PŠENKA, M. - JÄRVI, M. - ŠÍSTKOVÁ, M. - KAŽIMÍROVÁ, V. - HOLOTA, T. 2018. Noise analysis at different technological solutions of milking devices. In Applied Engineering in Agriculture, vol. 34, no. 6, pp. 921-927.

NOYA, I. - GONZÁLEZ-GARCÍA, S. - BERZOSA, J. - BAUCELLS, F. - FEIJOO, G. - MOREIRA, M. T. 2018. Environmental and water sustainability of milk production in Northeast Spain. In Science of the Total Environment, vol. 616-617, pp. 1317-1329.

RASMUSSEN, J. B. - PEDERSEN, J. 2004. Electricity and water consumption at milking. Aarhus, Denmark : Danish Agricultural
Advisory Service, National centre, Building and Technique, $42 \mathrm{pp}$. RIDOUTT, B. G. - PFISTER, S. 2010. Reducing humanity's water footprint. In Environmental Science \& Technology, vol. 44, no. 16, pp. 6019-6021.

ROBINSON, A. D. - GORDON, R. J. - VANDER-ZAAG, A. C. - RENNIE, T. J. - OSBORNE, V. R. 2016. Usage and attitudes of water conservation on Ontario dairy farms. In Applied Animal Science, vol. 32, no. 2, pp. 236-242.

PŘIKRYL, M. - VACULÍK, P. - CHLÁDEK, L. - LIBICH, L. - SMETANOVÁ, I. 2016. The human factor's impact on the process of milking. In Agronomy Research, vol. 14, no. 5, pp. 1659-1670.

PŘIKRYL, M. - VACULÍK, P. - SMEJTKOVÁ, A. - HART, J. - NĚMEC, I. 2015. Producing the vacuum in modern drawn milking systems. In Agronomy Research, vol. 13, no. 1, pp. 253-260.

SULTANA, M. N. - UDDIN, M. M. - RIDOUTT, B. G. - PETERS, K. J. 2014. Comparison of water use in global milk production for different typical farms. In Agricultural Systems, vol. 129, pp. 9-21.

THOMSON, A. - CORSCADDEN, K. 2018. Water Use in Dairy Industry - Evaluating Automatic Milking System in Nova Scotia. Dalhousie University and NSFA Federation of Agriculture, $18 \mathrm{pp}$.

VANDER-ZAAG, A. C. - BURTT, S. - VERGÉ, X. - PIQUETTE, S. WRIGHT, T. - KROEBEL, R. - GORDON, R. J. 2018. Case study: Water budget of a dairy farm with a tie-stall barn for milk cows and summer pasturing of heifers and dry cows. In Applied Animal Science, vol. 34, no. 1, pp. 108-117.

WILLIAMS, J. 2009. Dairy shed water - How much do you use. Melbourne : Department of Primary Industries, 44 p. ISBN 9781742176253.

WHITE, R. R. 2016. Increasing energy and protein use efficiency improves opportunities to decrease land use, water use, and greenhouse gas emissions from dairy production. In Agricultural Systems, vol. 146, pp. 20-29. 